\title{
An overview of the state of research on women and politics in Spain
}

\author{
CELIA VALIENTE \\ Universidad Carlos III de Madrid, Spain
}

\begin{abstract}
This article is an overview of quantitative and qualitative research on women and political decision-making in Spain. Ten parts of the literature are examined including: government and legislative; public administration; political parties; employers' organizations; unions; pressure groups and lobbies; social movements and NGOs and womens' policy machinery. The future prospects of filling the enormous gaps in the research are negative, given the weak institutionalization of gender studies in Spain.
\end{abstract}

\section{Introduction}

This article offers an overview of research on women and political decisionmaking in Spain. The aims of this report are: to describe the existing state of research; to identify the gaps in coverage; to indicate which gaps should be prioritized for future research; and to supply a bibliography of existing research. Since this is a short article, it is not totally exhaustive but it provides a general picture of the state of research on the matter. I have selected works using the following criteria: the main (or one of the main) topic is women and political decision-making in the democratic period (1975-1997); works are published (with some exceptions); and works contain empirical research.

An article on existing research on any topic might give the reader the impression that many relevant works have already been published, the question has been closely investigated, and there are few aspects which need further research. This is definitely not the case with women and political decisionmaking in Spain where the gaps in coverage are enormous. Study of women in Spanish politics is mainly descriptive, limited to the documentation of the weak presence of women in political decision-making. There are very few explanatory works which analyse why and how women are excluded from politics. Most authors are interested not only in describing but also in denouncing gender inequality, as is the case of most research about gender issues in Spain (Alberdi \& García de León 1990). There is therefore an elision in some pieces between scientific analysis and normative concerns. (Uriarte 1997a: 15). Prior to the 1980s hardly any analysis was made 
of women's political roles in and very little research has been undertaken since then (Ballarín et al. 1995: 170). ${ }^{1}$ In this overview I divide the literature on women and political decision-making into 10 sections; government and legislative, public administration, political parties, employers' organizations, unions, pressure groups and lobbies, social movements and NGOs and women's policy machinery. ${ }^{2}$ I conclude with some general remarks on the future prospects of filling gaps in the research.

\section{Government and legislative}

Data on the presence of women in the political elite are available from several sources, among them the reports made by the EU Expert Network on Women in Decision-Making which includes Spain. In general, the national level is better covered in all sources than the regional level and much better than the local level. At the national level, the Head of State is a constitutional monarch. Men have precedence over women in the inheritance of the Crown. No woman has ever occupied the position of Prime Minister in contemporary Spain. Quantitative data about the presence of women in the cabinet in the democratic period are available in: IM (1994b: 86) and Uriarte (1997b), among others. The percentage of women in the Spanish executive in 1997 was 26 percent. Spain is behind the Nordic countries or the Netherlands but ahead of other EU member states such as France, Great Britain, Germany or Italy (Uriarte 1997b: 58). Data on the number of female deputies and senators in the legislative can be found in: IM (1994a, 1994b: 79-82); and Uriarte (1997a,b), among others. In the lower chamber, the proportion of female MPS has risen throughout the whole democratic period, from 6 percent in the first parliamentary term to 24 percent in the current term. Spain is behind some countries, for instance, the Nordic states, but ahead of others such as France, Great Britain or Italy. Leftist parties have more female MPS than conservative parties. The presence of women in the lower chamber is the highest in the leftist coalition Izquierda Unida (IU) (33 percent), followed by the social democratic Partido Socialista Obrero Español (PSOE) (28 percent), and the conservative Partido Popular (19 percent) (Uriarte 1997b: 60).

At regional level data on the presence of women in the leadership are available for all regions: IM (1994b: 87). In 1993, seven regions had no women in the executive, two regions had fewer than 10 percent of women, five regions had between 10 and 20 percent of women (both included), two had 25 percent of women, and one region had 33 percent of women (IM 1994b: 87). The regional data on functional specialisation confirm a tendency that can be observed in all levels of government: that when women reach the leadership, they are usually in charge 'soft' issues such as education, 
culture, or health. Women are hardly ever in charge of those departments considered more important, that is, the economy, foreign affairs (when in existence) or the Home Office (Elizondo 1994; 64, Uriarte 1994: 234). Data on the presence of women in the regional assembly are available for all regions in: IM (1994b: 83). Their presence has increased throughout the democratic period; in 1993 women amounted to 14 percent of all regional MPS, although significant differences existed among regions (Uriarte 1997a).

At the local level, data on the presence of women in the leadership and the assembly are also available for the whole of Spain (IM 1994b: 88). This presence is lower than at the regional or national level; for example, in 1991 only 5 percent of mayors were women (IM 1994b: 8). The difference between the local and the other levels merits attention, since it is often argued that women have more chances of entering the political elite at the local level (Uriarte 1994: 234; 1997a: 28).

Generally speaking, qualitative studies that explain how and why women reach (or do not) decision-making positions in government are much more scarce than quantitative research which maps the presence of women in those positions. For instance, we know very little about the recruitment of female and male legislators, nothing more than some facts, such as that the proportion of single, separated and divorced people is higher among female deputies than among male deputies (Uriarte 1997a). This is an area where more research is badly needed.

Due to the scarcity of qualitative works on the topic, I can only make some conjectures. The unwillingness of men to designate women for decision making positions has been identified as one of the main factors hindering women's recruitment and promotion. The lack of role models is another factor which impedes the advancement of more women. I believe that women who are about to reach positions of power lack the example of other women who already occupy these positions. Widespread sexual harassment seems to be a feature of the culture of many organizations and institutions. Sexual harassment helps keep women in traditionally female positions, and impedes their reaching leading posts, which have traditionally been held by men (Barrio 1996).

Supply-side explanations of the weak presence of women among the political elite have been made. It is reasonable to expect that this type of study will be developed in the near future. In the 1970s, lack of education was identified as a major obstacle to the advancement of women in politics (for instance, Elorriaga 1976: 72). Since then, an increasing number of young women have been enrolled as students at the university. Nevertheless, even if women are now the majority of undergraduate students in the university as a whole, they are still a minority among graduate students, among those who complete the 
requirements to become doctors and among faculty members. This minority status seems to be an obstacle for women with political aspirations, because the university is a platform from which to reach political leadership. For instance, in legislative term 1989-1993, 38 deputies were university professors or lecturers (García de León 1991: 29). In addition, even if the level of education is in general the same for young women and men, this is not the case for the population of all ages. The difference in education is an impediment for women to run for office, since this political activity usually correlates with a high level of education (Uriarte 1997b: 67). The supply of women decisionmakers is seriously hampered by the difficulties of combining professional and family responsibilities.

\section{Public administration (senior grades)}

Data about senior female civil servants of the central state that is public administration $^{3}$ (senior grades) can be found, for instance, in: IM (1993b, 1994b: 84) and MAP (1990). In 1993, women were to 42 percent of civil servants but were under-represented among the higher civil servants: only 26 percent of group A civil servants ${ }^{4}$ were women (IM 1994b: 84). Data on the presence of women in regional public administration are available for some regions, for instance, Catalonia (Matas 1996). I do not know of any quantitative study on highly-ranked civil servants at the local level for the whole territory of Spain.

There are very illuminating qualitative studies on the movement of women through the hierarchies of public administration. The recruitment and promotion processes in the civil service are supposed to be entirely meritocratic, except for the highest ranks which are occupied by people directly nominated by political authorities. In spite of this meritocratic principle, some senior female civil servants reported having been discriminated against in a public exam (oposición) in favour of male candidates. The examining board (tribunal de oposición) assumed that male candidates 'needed' the promotion more than the female candidates, because proportionally more men than women were breadwinners. It was also presumed that men naturally had professional ambitions that women lack. Therefore, female candidates 'could wait' for another opportunity (García de León 1991: 34). The scarcity of women on examining boards seems to be an obstacle for the recruitment of women to senior grades in the civil service (IM 1993b: 32-33).

A recent interesting study of career patterns of female and male senior civil servants was based on a self-administered questionnaire distributed in 1992 to a representative sample of women and men belonging to the highest group of the central state civil service (group A) (IM 1993a). The study 
analysed the perceptions of group A officials (of both sexes) of the barriers to professional advancement of senior women officials. Many of those interviewed perceived that public administration is a milieu more 'friendly' to men than to women and identified sexist stereotypes, discrimination, and family responsibilities as obstacles to the professional advancement of women. 64 percent of the women and 27 percent of the men interviewed affirmed that it was necessary to enforce equality measures to promote women to highly-ranked positions in the civil service (IM 1993a: 9). ${ }^{5}$ This study is very important because it identifies the problems for the promotion of women that exist in the most qualified sector of the female working population (group A officials have four or more years of university education), and in public service, which theoretically, as a professionalised environment, should be very friendly to women.

Studies on the gender biases in the culture of public administration have also been carried out at the regional level. In their study of Catalonia Gutiérrez and Pastor (1996) interviewed a sample women who occupied senior positions (jefaturas de servicio and subdirecciones). Their respondents described the institutions where they worked. They reported no explicit discrimination in the formal methods of recruitment and promotion. The officials interviewed identified several features of the culture of the organization that inhibit the promotion of women. For example, that senior officials had to work very long hours, far beyond the official schedule. These requirements are not absolutely necessary for the good performance of the job (although these may be necessary given the current organization of the administration). Since the majority of men could fulfil these requirements better than the majority of women the long hours culture was a barrier to women

\section{Political parties}

Research on political parties is more scarce than on government or the bureaucracy. Data on political parties are easier to obtain at the national than at the regional level, and the latter much easier than at the local level. No woman has ever occupied the highest position in party leadership in a major political party in contemporary democratic Spain. There are some quantitative data on women in leadership positions in the three main nationally-based parties: the PSOE; the PP; and the IU. Women achieve the remaining leadership positions to a lesser extent than men. The proportion of women in top posts (the highest committee) in leftist parties is higher than in conservative parties: 35 percent in the leftist IU, 30 percent in the social democratic PSOE, and 19 percent in the conservative PP (in 1994). This contrasts with the higher proportion of female members in conservative parties (Uriarte 1995, 1997a, b, c). When 
women reach posts of power, they are usually in charge of the women's department or of departments of social issues (Ortiz 1987: 126-127).

As for candidates, the number of women on electoral lists has been increasing over the last few decades in the majority of political parties. Nevertheless, women hardly ever occupy the first positions on these lists (Ortiz 1987: 129-139). The proportion of women among the candidates with serious chances of winning a seat is higher in the leftist than in the conservative parties, and higher for parties with a small or no presence in the chamber (Barbadillo et al. 1990).

Quantitative data on female membership of the main nationally-based political parties is available in: IM (1992: 64; 1994b: 76). Generally speaking, the number of female members is much smaller than male members. Conservative parties have higher proportions of female members than leftist parties. In 1991, the female membership was 30 percent in the conservative PP, 21 percent in social democratic PSOE, and 18 percent in the Communist party (Partido Comunista de España, PCE, 1989 data). The average of female party membership in Spain (24 percent) is one of the lowest of European countries (Uriarte 1997c: 192-193). Female members of political parties tend to have husbands, parents, and female friends who are also members (Ortiz 1987: 122). Uriarte (1997c: 194) has argued that the gender gap will probably diminish in the future for most parties. She illustrated this proposition with the example of membership of the PSOE by age group and sex in the late 1980s. In this case, it was evident that the gender gap diminished for people younger than 40 .

Echoing the experience of other European parties, it appears that the number of female candidates of any political party (in electoral processes in contemporary Spain) increases when the probability of obtaining votes diminishes. Although all parties now use the presence of women on their lists in an attempt to win votes, male politicians close ranks around male candidates when the party has any real possibility of winning a seat in Parliament, or in the Cabinet (García de León 1996: 171-172; Uriarte 1997b). As a former female political leader at the provincial level from the centre-right Unión de Centro Democrático (UCD) affirmed, when answering the question about how men behave when electoral lists are being set: "Men fight like wild animals. In addition to the 'erótica del poder' ${ }^{6}$ many believe that they are going to win economic privileges"7 (Garcia de León 1991: 45).

It has also been argued (but has not been empirically tested) that other things being equal, women have a higher probability of being elected as legislators the bigger the population in the electoral district. In Spain, the number of female candidates in each district who eventually win a seat is so 
low that sometimes this pattern cannot be observed (García de León 1996: 173).

Relegation to the bottom of the lists not only deprives candidates of the possibility of gaining political office but it also excludes them from public view. Candidates who head the lists usually lead the electoral campaign in Spain. This is an excellent chance for candidates to gain experience as political leaders. Most female candidates cannot avail themselves of this opportunity (García de León 1991: 39).

The two main obstacles to women's political promotion are the electorate's differential trust in male and female candidates and the culture of political parties. Uriarte (1997b: 69) has demonstrated that a significant proportion of voters trust male candidates more than female candidates. This difference in trust acts as a barrier against women in the process of recruiting potential politicians. In their investigations of party cultures Gaitán and Cáceres (1995) studied the image of women in the documents of the main political parties (electoral programs, statutes, etc.) from 1977 to 1994. Women are presented in these documents as individuals who participate mainly in the economic and social spheres. This is a very positive image, given the fact that from the second half of the 1930s until 1975, Spain was governed by a right-wing authoritarian regime that actively opposed the advancement of women's rights and status. Francoist policy-makers defined motherhood as the main duty of women towards the state and society and affirmed that the role of mothering was incompatible with other roles, such as that of waged worker. The willingness of political parties to present positive images of women does not extend to political images. To the extent that the cultures of political parties are reflected in their documents, these are organizations whose political world is male.

The impact of party quotas on the representation of women has also been successful. The Spanish case shows that when a quota is introduced in a party, the number of female legislators from that party elected in the subsequent election increases significantly. Moreover, although only leftist parties have until now introduced quotas, their effect tends to spread to other parties who are pressured by their achievements. Conservative parties (which have no quota) increased the number of their female representatives after the introduction of the quota in leftist parties (Uriarte 1997b: 69-70).

Vázquez has hypothesized (but not empirically proved) that generally speaking, women and men become members of political parties for different reasons. Women tend to participate in politics in order to help others or change and improve society. These altruistic motives usually orient them to work in types of social or personal projects other than conventional politics. Relatively few women engage in political party work in order to achieve 
prestige, professional upward mobility and economic privileges. These are precisely the reasons that induce some men to be politically active and to try to reach leadership positions in political parties (Vázquez 1989: 16).

\section{Employers' organizations, unions, pressure groups and lobbies}

No study of the leaders, activists, and members of employers' associations has focused on differences between women and men. Some female employers have created their own organizations and there are organizations of female managers, but neither has been studied. It has been argued that generally speaking, most female employers know that employers' associations exist, but do not know exactly what their functions are. Some female employers join these associations for reasons of prestige. In general, female employers think that these organizations are of little use so while they join employers' associations, they pay membership fees but do not attend the meetings. Other female employers prefer to solve their own problems through their own means (for instance, hiring a lawyer) rather than using the services and support provided by employers' associations (to which they do not belong) (Área de Estudios Territoriales y de Diseño 1986: 133-135).

Data on the proportion of female members in the two main trade union confederations, indicated in 1992, that percentage was 21 percent in the Comisiones Obreras (CCOO) and 18 percent in the Unión General de Trabajadores (UGT). In the CCOO 13 percent of the CCOO congress delegates were women, and this was the case of the 8 percent UGT congress delegates. Lastly, 4 percent of the Directive Committee of the UGT were women (IM 1994b: 77). I do not know of any qualitative study on this topic. To my knowl-

edge, no one has yet made quantitative or qualitative studies of the presence of women as leaders, activists and members of pressure groups and lobbies. In this area, we do not even have the most basic quantitative data (Uriarte 1997a: 27).

\section{Social movements and NGOs}

Quantitative data on the presence of women as leaders, activists and members of social movements and NGOs in our time have not yet been systematically gathered (Uriarte 1997a: 27). This is something to be regretted, given the fact that a significant proportion of the women who belong to an organization of any kind are members of NGOs (voluntary associations and charities), and not of political parties, trade unions, or feminist groups. For instance, a study of the situation of women in the region of Extremadura documented that in 
the Fall of 1986, 27 percent of women living in that region belonged to one or more associations. Out of the total number of women in the region, 16 percent belonged to an association of parents of children attending school (asociaciones de padres de alumnos), 8 percent to religious organizations, and 3 percent to neighbor's organizations (Asamblea de Extremadura 1988: 230).

What we now know is that women belong to a lesser extent than men not only to conventional political organizations (such as parties or unions) but also to other associations, such as cultural, environmentalist, or professional organizations, sports clubs, neighbors' associations, or human rights groups. Female members only outnumbered male members in charity associations and women's groups (Uriarte 1997c: 196).

In the Spanish context 'women's organizations' and 'feminist organizations' are not at all synonymous. It has been documented that in some regions, the majority of the existing women's groups are not feminist groups. For example, the aforementioned study of Extremadura women shows that in the 1980s the most frequent type of women's groups in that region were housewives' associations. These represented 50 percent of all women's groups in the province of Cáceres, and 30 percent in the province of Badajoz. The second most frequent type of women's organizations were widows' associations and cultural organizations (Asamblea de Extremadura 1988: 230). The feminist movement is not a mass movement: Durán and Gallego (1986: 205) estimated that by the mid-1980s the number of feminist activists accounted for less than 0.1 percent of adult women.

There are a number of qualitative studies of the feminist movement current and past (a.o.: Astelarra 1989; Di Febo 1979; Durán \& Gallego 1986; Escario et al. 1996; Folguera 1988; Kaplan 1992; Scanlon 1976, 1990; Threlfall 1985, 1996). Nevertheless, generally speaking, these studies do not analyse the processes of power seeking and power maintenance within these organizations. As in other Western countries, in relation to internal power, feminist groups in Spain have been and are of two types: some are hierarchical, others are not. Feminists in Spain are aware of the advantages and disadvantages of hierarchical and non-hierarchical structures. The work of Jo Freeman on the potential tyranny of structurelessness has been translated and read by activists. In spite of this awareness, no study of how and by whom power is exercised within feminist organizations has been conducted.

\section{Women's policy machinery}

The main women's machinery at central-state level is the Institute of the Woman (Instituto de la Mujer, IM) founded in October 1983. There are some 
studies of the process of establishment of the IM, of IM's functions, of the relationships between femocrats and the feminist movement, and of the participation of IM officials on the policy-making process in matters of gender equality (Threlfall 1996; Valiente 1995b, 1997b). The IM has neither the power nor the budget to formulate and implement most gender equality policies. Instead, it has to convince other state offices to elaborate women's equality policies. The IM is also in charge of controlling the implementation stage of gender equality policies at the central-state level.

It is important to bear in mind that research on public policy is still very underdeveloped in Spain (Colino et al. 1994: 530-531). There is not (yet) a study which systematically assesses the scope of all laws and policies on equality between women and men, although attempts in this direction include Threlfall (1996) and Gil (1996). Some studies have already been done (at the central-state level) about: public policies for working women (Valiente 1997a); child care policies (Valiente 1995a); policies against violence against women (Valiente 1996a); family policy (Valiente 1996b); and the regulation of sexual harassment in the work place (Valiente 1997c). All these works are studies of the policy-making process in relation to gender equality, but pay little attention to the evaluation of the policies (an exception is Bustelo 1997).

Thanks to such studies of gender equality policy in Spain, we know some characteristics of this policy area at the national level. We also can begin to detect the role played by a female power elite: the femocrats. The establishment of most gender equality policies has been promoted in Spain in the last two decades by state feminists, and/or feminists within trade unions and parties, rather than by the women's movement or by both, as in other countries. Feminists within the women's policy machinery, unions and parties have been very influential in the first stages of the policy-making process (problem definition and agenda setting) but not in the last stages (policy formulation and policy implementation). Their influence has been mainly on problem definition. These feminists have been quite active in the task of converting 'private' matters into 'public' problems. As a consequence, important political and social actors and some sectors of public opinion have begun to conceptualize issues such as rape within marriage or sexual harassment in the work place not as 'facts of life' or a citizens' own business, as they had done in the past, but as social problems which deserve public attention (and solutions).

Feminists within women's policy machinery, political parties and trade unions have also had a positive record of agenda-setting. They have succeeded in persuading other political actors to introduce equality goals onto their agendas. In fact, had they not been active, many state units would probably never have established equality measures, or would have established them 
later than they actually did. It is impossible, however, to make a similarly positive assessment of the importance of the performance of feminists in the stages of policy formulation and implementation. Specific and concrete measures to tackle various types of gender inequalities are actually formulated within the ministries and/or in Parliament. Ministries in general try hard to preserve and reinforce their own powers. Feminists within the IM, parties and unions have little influence in these two arenas when a choice is being made from among the various alternatives available to address a problem. The implementation of gender equality measures is in the hands of state units (mainly the ministries) for which gender equality is not a priority. Hence, equality programs are not usually implemented in Spain and are often dismissed as merely 'symbolic', in the sense that they do not solve the problems that they are supposed to address. Nevertheless, equality policy might serve important functions, among them, to be a first step in the fight against gender inequalities, and to help persuade the population to behave in a more gender-equal manner (Valiente 1997c).

We hardly know anything about the machinery to implement laws and policies on equality between women and men at the regional level. Two pioneer descriptive studies have been made by Elizondo and Martínez (1995) for the Basque country and by Granados (1997) for Andalusia. Astelarra (1996: 263) has argued (but not empirically tested) that although the formal characteristics of women's machineries at the regional level are very similar, the de facto capacity of these machines to promote equality policies varies a lot. Similarly, the topic of laws and policies on equality between women and men at the regional level is practically unknown. Two exceptions to this general rule are the study undertaken by Elizondo and Martínez (1995) on the Basque country and that made by Bustelo (1997) on the evaluation of national and regional equality plans. ${ }^{8}$ This is a topic which needs much more research.

Similarly, women's machinery at the local level constitute an almost unexplored territory for researchers. Local authorities are believed to do less than those of the regional authorities. Local authorities tend to run programs for especially disadvantaged women, while central state and regional authorities have developed programs for women in very different situations and not only for those in the most adverse circumstances (Mendizábal \& Ortiz 1995).

\section{Prospects}

In addition to the gaps in research already identified in this article, the main gaps in research on women in politics are explanatory (and not only descriptive) studies; comparative studies; empirical studies which attempt to contribute to international debates on women and decision-making; the eval- 
uation of policies which aim to reduce the weak presence of women in key decision-making areas; and publications of wide circulation (see below).

The main difficulties in conducting this research are: the lack of fundamental studies; the negative image that gender issues has among most researchers; the low degree of institutionalization of gender studies in Spain; and the scarcity of female political scientists. Therefore, prospects to fill in research gaps are not positive. A related problem is the inadequate dissemination of research already done. It is often the case that publications on gender hardly circulate and that it is very difficult to have access to them or even to know that they exist. Therefore, there is a continual danger in this area of knowledge of replicating studies already undertaken.

Uriarte (1997a: 17-18) has convincingly argued that in Spain, the negative image of gender research among most scholars is due to historical development of this area of knowledge. Most people who do studies on gender happen to be feminist women. This is a practical obstacle for the development of research on women and decision-making, because being a feminist is regarded negatively by society and by the academic world. Gender research is a risky option for scholars, who may be denigrated by others (whether openly or not). It is not therefore surprising that the degree of institutionalization of gender studies in Spain is generally low. The central organizational unit of the Spanish university system is the department. No gender studies department exists. ${ }^{9}$ It is not currently possible to get a degree in gender studies in the university. This means that all scholars who do research on gender develop their academic careers in departments dedicated to other disciplines, such as international relations, public law or methodology in social sciences, among others. Generally speaking, such scholars teach courses not on gender but on other topics. To some extent this is also true for research: if they want to fit in to their departments, scholars have to publish on areas other than gender. If they chose to dedicate some of (or all) their time and resources on research on gender, they risk not fitting in to their departments. This institutional framework is a powerful barrier to many scholars interested in gender (Uriarte 1997a).

In addition, the overwhelming majority of people who wish to do research on women and political decision-making are women but there are very few female political scientists. In the Spanish university system, there are two types of tenured positions: catedráticos (the highest posts) and profesores titulares. To my knowledge, in the field of political science there are two women who are catedráticas and only a few more who are profesoras titulares. Most women who are active in political science are either lecturers who do not occupy tenured positions or graduate or undergraduate students. There is still a scarcity therefore, of qualified professionals with permanent positions who 
could carry out studies on women in political decision-making. The major pool of potential researchers on this matter is formed by graduate students who plan to write a doctoral dissertation (personal interview, Mayte Gallego, 22 April 1997). Nevertheless, it is unlikely that many of them would be interested in working on such a topic. The main reasons are two: the already mentioned "risks" of this area of research, and the small number of potential $\mathrm{Ph} . \mathrm{D}$. advisors, given the small number of specialists in gender issues among scholars in tenured positions at the university.

\section{Acknowledgments}

This article originated as my contribution to an overview of the research on women in political, economic and social decision-making covering the 15 European Union (EU) countries, Norway and the institutions of the EU. The overview was financed by the European Commission (DGV), whose sponsorship is acknowledged here. I would also like to thank the editor for helpful comments on an earlier draft.

\section{Notes}

1. A concise overview of the art of research on women can be seen in: Alberdi \& García de León (1990) for sociology; Nash $(1991,1996)$ for history; Uriarte (1997a) for political science; and Ballarín et al. (1995) for university research in all academic disciplines. Such research has more frequently been done in history and sociology There is no tradition in Spain of making comparative studies in social sciences (Uriarte 1997a: 27). The works commented on here usually use gender as the main dimension in the analysis. Works that deal with other topics but use gender as one of the many variables are not included here because this sort of research is still very rare in Spain (Uriarte 1997a: 15-16).

2. Since the 1970s, institutions with the specific purpose of promoting gender equality have been established, developed (and sometimes even dismantled) in most industrial countries. Such institutions have been labelled in social science literature 'state feminist' institutions or bureaucracies, or women's machineries. The people who work there are termed 'state feminists' or 'femocrats' (Stetson \& Mazur 1995).

3. In this article, the terms 'public administration', 'civil service' and 'bureaucracy' (and subsequently 'civil servants' and 'bureaucrats') are synonymous.

4. Group A officials perform high management functions. The minimum educational requirement to belong to group A is four years of university.

5. It is important to note that there are no affirmative action programs in the Spanish bureaucracy. Moreover, there is no special course, lecture or seminar on gender equality in the training programs of highly-ranked officials (Gallego \& Mó 1996).

6. Erótica del poder literally means 'power erotic' and describes the process by which power exercises such an intense attraction to some people that it can be compared with an aphrodisiac.

7. All translations in this article are by the author. 
8. An equality plan is a policy instrument which consists of a set of gender equality measures to be undertaken by different state units in a given period.

9. Gender research has acquired a certain degree of institutionalization, for instance, with the creation of inter-departmental gender research institutes.

\section{References}

Alberdi, I. \& García de León, M.A. (1990). La sociología de la mujer en España, in S. Giner \& L. Moreno (eds.), Sociología en España. Madrid: Consejo Superior de Investigaciones Científicas and Instituto de Estudios Sociales Avanzados.

Área de Estudios Territoriales y de Diseño (1986). La mujer empresaria y trabajadora autónoma (unpublished).

Asamblea de Extremadura (1988). La situación de la mujer en Extremadura. Mérida: Editora General de Extremadura.

ASDO [Association of Women for Development and the Struggle Against Social Exclusion] (1996). Survey on Participation by Women in Decision Making in Italy (Final Report, Draft). Rome: ASDO.

Astelarra, J. (1989). The transition to democracy in Spain, in Y. Cohen (ed.), Women and Counter-Power. Montréal and New York: Black Rose Books.

Astelarra, J. (1996). Políticas de igualdad de oportunidades en España y el Reino Unido, in: C. Brullet \& P. Carrasquer (eds.), Sociología de las relaciones de género: congreso de sociología, Granada, 1995. Madrid: IM.

Ballarín, P. et al. (1995). Los estudios de las mujeres en las universidades españolas 19751991: Libro Blanco. Madrid: IM.

Barbadillo, P. et al. (1990). La mujer en el Congreso de los Diputados: análisis de su participación en las candidaturas electorales, Revista Española de Investigaciones Sociológicas 52: $101-135$.

Barrio, E. (1996). Historia de las transgresoras: la transición de las mujeres. Barcelona: Icaria.

Bustelo, M. (1997). ¿Cómo se evalúan las políticas públicas de igualdad de género?: un análisis comparativo de las evaluaciones de los planes de igualdad estatal y autonómicos. Paper presented at the Third Spanish Congress of Political Science and Public Administration, Salamanca (Spain), 2-4 October 1997.

Colino, C. et al. (1994). Political studies in Spain: An annotated Bibliography of Recent Work, European Journal of Political Research 25 (4): 527-536.

Di Febo, G. (1979). Resistencia y movimiento de mujeres en España 1936-1976. Barcelona: Icaria.

Durán, MA. \& Gallego, MT. (1986). The women's movement in Spain and the new Spanish democracy, in D. Dahlerup (ed.), The New Women's Movement: Feminism and Political Power in Europe and the USA. London: Sage.

Elizondo, A. (1994). Comparación de la presencia de mujeres entre los diferentes niveles institucionales de la CAV, in Asociación Vasca de Sociología (ed.), Actas del tercer congreso vasco de sociología: sociología para una sociedad en marcha. Bilbao: Asociación Vasca de Sociología.

Elizondo, A. \& Martínez, E. (1995). Presencia de mujeres y política para la igualdad entre los sexos: el caso de las instituciones políticas vascas (1980-1994), Revista de Estudios Políticos 89: 345-368.

Elorriaga, G. (1976). Liderazgo político. Madrid: Sala. 
Escario, P. et al. (1996). Lo personal es político: el movimiento feminista en la transición. Madrid: IM.

Folguera, P. (1988). De la transición política a la democracia: la evolución del feminismo en España durante el período 1975-1988, in P. Folguera (ed.), El feminismo en España: dos siglos de historia. Madrid: Pablo Iglesias.

Gaitán, J.A. \& Cáceres, M.D. (1995). La mujer en el discurso político, Revista Española de Investigaciones Sociológicas 69: 125-147.

Gallego, Mayte. Personal interview, Madrid, 22 April 1997.

Gallego, M.T. \& Mó, O. (1996). Public Administration, in M-L. Kearney \& A.H. Ronning (eds.), Women and the University Curriculum: Towards Equality, Democracy, and Peace. London and Paris: Jessica Kingsley and Unesco.

García de León, M.A. (1991). Las mujeres políticas españolas (un ensayo sociológico). Madrid: Dirección General de la Mujer de la Comunidad de Madrid.

García de León, M.A. (1996). Las élites políticas femeninas, in M.A. García de León et al. (eds.), Sociología de las mujeres españolas. Madrid: Complutense.

Gil, J.M. (1996). Las políticas de igualdad en España: avances y retrocesos. Granada: Universidad de Granada.

Granados, E. (1997). El Instituto Andaluz de la Mujer: organización, presupuesto y actuaciones, Paper presented at the Third Spanish Congress of Political Science and Public Administration, Salamanca (Spain), 2-4 October.

Gutiérrez, C. \& Pastor, I. (1996). Las mujeres en la Administración Publica catalana (Estudio sociológico sobre la situación de las mujeres en la carrera administrativa), in C. Brullet \& P. Carrasquer (eds.) Sociología de las relaciones de género: Congreso de Sociología, Granada, 1995. Madrid: IM.

Instituto de la Mujer [IM] (1992). La mujer en cifras 1992. Madrid: IM.

IM (1993a). Estudio sociológico sobre la carrera administrativa de las mujeres. Madrid: IM.

IM (1993b). Las mujeres en la Administración del Estado: explotación de datos secundarios. Madrid: IM.

IM (1994a). Elecciones 1993: mujeres en el Congreso y en el Senado. Madrid: IM.

IM (1994b). La mujer en cifras: una década, 1982-1992. Madrid: IM.

Kaplan, G. (1992). Contemporary Western European Feminism. London: UCL Press and Allen \& Unwin.

MAP [Ministerio para las Administraciones Públicas] (1990). La mujer en la administración del Estado. Madrid: MAP.

Matas, J. (1996). Las élites políticas de la Administración: los altos cargos de la Generalitat de Cataluña. Barcelona: Cedecs.

Mendizábal, G. \& Ortíz, E. (1996). Del discurso de la igualdad a los planes de igualdad de oportunidades entre hombres y mujeres: análisis de la Comunidad Autónoma Vasca, in C. Brullet \& P. (eds.), Sociología de las relaciones de género: Congreso de Sociología, Granada, 1995. Madrid: IM.

Nash, M. (1991). Dos décadas de Historia de las mujeres en España: una reconsideración, Historia Social 9: 137-161.

Nash, M. (1996). Historia e Historiografía de las mujeres españolas, in M.A. García de León et al. (eds.), Sociología de las mujeres españolas. Madrid: Complutense.

Ortiz, C. (1987). La participación de las mujeres en la democracia (1979-1986). Madrid: IM.

Scanlon, G. (1976). La polémica feminista en la España contemporánea (1868-1974). Madrid: Siglo XXI. 
Scanlon, G. (1990). El movimiento feminista en España, 1900-1985: logros y dificultades, in J. Astelarra (ed.), Participación política de las mujeres. Madrid: Centro de Investigaciones Sociológicas and Siglo XXI.

Stetson, D.M. \& Mazur, A.G. (eds.) (1995). Comparative State Feminism. Thousand Oaks, CA: Sage.

Threlfall, M. (1985). The women's movement in Spain, New Left Review No: 44-73.

Threlfall, M (1996). Feminist politics and social change in Spain, in M. Threlfall (ed.), Mapping the Women's Movement: Feminist Politics and Social Transformation in the North. London and New York: Verso and New Left Review.

Uriarte, E. (1994). Las tranformaciones en el papel de la mujer, Inguruak: Revista Vasca de Sociología y Ciencia Política 10: 221-237.

Uriarte, E. (1995). Mujer y política en España, Sistema 124: 121-136.

Uriarte, E. (1997a). Estudios de mujeres y política en España, in E. Uriarte \& A. Elizondo (eds.), Mujeres en política: análisis y práctica. Barcelona: Ariel.

Uriarte, E. (1997b). Las mujeres en las élites políticas, in E. Uriarte \& A. Elizondo (eds.), Mujeres en política: análisis y práctica. Barcelona: Ariel.

Uriarte, E. (1997c). Pautas de cultura política y participación en España, in E. Uriarte \& A. Elizondo (eds.), Mujeres en política: análisis y práctica. Barcelona: Ariel.

Valiente, C. (1995a). Children first: Central government child care policies in postauthoritarian Spain (1975-1994), in J. Brannen \& M. O'Brien (eds.), Childhood and Parenthood: Proceedings of ISA Committee for Family Research Conference on Children and Families, 1995. London: Institute of Education/University of London.

Valiente, C. (1995b). The power of persuasion: The Instituto de la Mujer in Spain in D.M. Stetson \& A. Mazur (eds.), Comparative State Feminism. Thousand Oaks, CA: Sage.

Valiente, C. (1996a). Partial achievements of central-state public policies against violence against women in post-authoritarian Spain (1975-1995), in C. Corrin (ed.), Women in a Violent World: Feminist Analyses and Resistance Across 'Europe'. Edinburgh: Edinburgh University Press.

Valiente, C. (1996b). The rejection of authoritarian policy legacies: Family policy in Spain (1975-1995), South European Society and Politics 1(1): 95-114.

Valiente, C. (1997a). Políticas de género en perspectiva comparada: la mujer trabajadora en Italia y España (1900-1996). Madrid: Universidad Autónoma de Madrid.

Valiente, C. (1997b). State feminism and gender equality policies: the case of Spain (198395), in F. Gardiner (ed.), Sex Equality Policy in Western Europe. London: Routledge.

Valiente, C. (1997c). The regulation of sexual harassment in the workplace in Spain, in B. Hobson \& A.M. Berggen (eds.), Crossing Borders: Gender and Citizenship in Transition. Stockholm: Swedish Council for Planning and Coordination.

Vázquez, M. (1989). Espagne: Étude de cas national. Paper prepared for the Expert Group Meeting on Equality in Political Participation and Decision-Making, Vienna, 18-22 September 1989.

Address for correspondence: Dr Celia Valiente, Departamento Humanidades, Ciencia Política y Sociología, Universidad Carlos III de Madrid, 28903 Getafe, Madrid, Spain Phone: +34 91530 6009; Fax: +34 91624 9574; E-mail: valiente@ hum.uc3m.es 